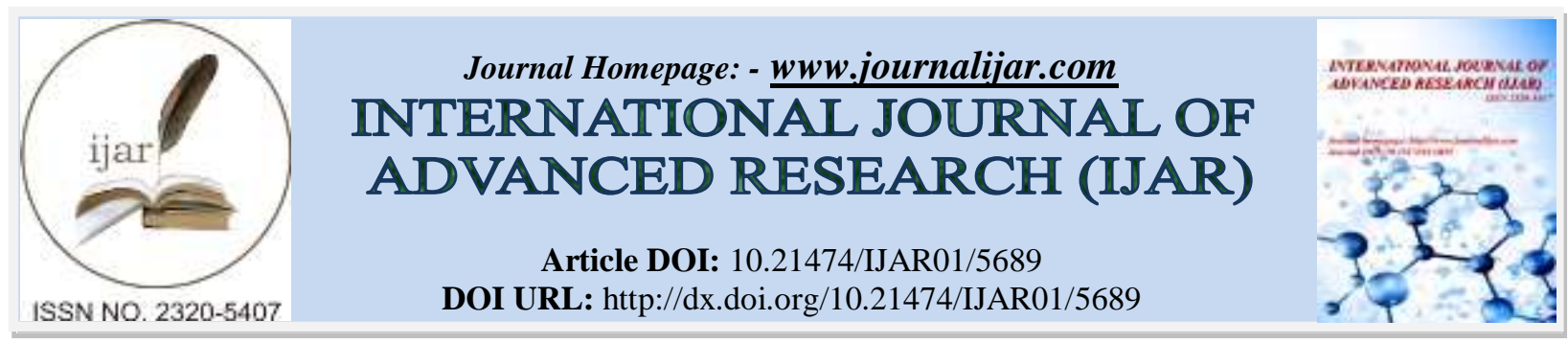

RESEARCH ARTICLE

\title{
DISTAL PENIL HYPOSPADIAS REPAIR WITH AND WITHOUT DARTOS FASCIA FLAP, A COMPARATIVE STUDY.
}

Mohamed Fathy, Alaa Elsayed, Omar shaker and Mohamed M. Khedre.

Pediatric surgery unit, Minia university, Faculty of Medicine - Minia University.

\section{Manuscript Info}

Manuscript History

Received: 22 August 2017

Final Accepted: 24 September 2017

Published: October 2017

\section{Abstract}

Background: Hypospadias is the most common anomaly in male genital tract. The single stage Snodgrass tubularized incised plate (TIP) repair is widely accepted for treatment of distal hypospadias.

Objective: To evaluate the efficacy of spongioplasty with or without Dartos flap for treatment of primary hypospadias.

Patients and Methods: A prospective study was performed including 40 cases with mid- and distal primary penile hypospadias undergoing TIP from January 2014 to January 2015, at Minia University Hospital, Egypt. The cases were divided into two groups of equal number. In group I, 20 cases underwent TIP without dartos fascia flap. In group II, 20 cases managed by adding a dartos fascia flap as an intermediate layer for covering neourethra after spongioplasty. The assessed parameters were force and caliber of the urinary stream, gapping of the suture line, fistula formation, meatal stenosis, stricture of the urethra, complete disruption of the repair, and post operative bleeding.

Results: There was a significant less operative time in group I (46.25 \pm 7.58 minutes versus $67.5 \pm 15.76$ minutes, $\mathrm{P}<0.001)$. There were no significant differences in incidence of intraoperative bleeding $(10 \%$ and $20 \%$ respectively), incidence of urethrocutaneous fistula (10\% and $15 \%$ respectively), and incidence of meatal stenosis (10\% and 5\% respectively).

Conclusion: Spongioplasty only in TIP repair without using daros flap is relatively safe and rapid technique.

Copy Right, IJAR, 2017,. All rights reserved.

\section{Introduction:-}

Hypospadias is the most common male genital tract anomaly with approximately $0.8-8.2$ per 1000 male newborns [1]. Tubularized Incised Plate (TIP) urethroplasty, as described by Snodgrass is the method of choice for treating distal and mid shaft hypospadias with a low complication rate [2].

Many methods have been described in the literature for the interposition of tissue to cover the neo-urethra including island dorsal subcutaneous flap, Dartos flaps, de-epithelized local penile skin, preputial flap, paraurethral tissue, spongioplasty, or tunica vaginalis flaps [3].

There are different techniques for harvesting dartos flap. The dorsal dartos flap is mainly used by many surgeons, however there is still no consensus over the ideal interposing tissue in TIPU. Because of edema, necrosis of skin, 
hematoma and torque with mobilization of the dorsal Dartos flap its role as an interposing tissue had been questioned [4].

Therefore, the aim of the present study was to evaluate the value of the dartos flap as a second layer for covering neourethra, in preventing urethrocutaneous fistula, infection and meatal stenosis after TIP using spongioplasty.

\section{Subjects And Methods:-}

The study was conducted at Department of Pediatric surgery.The study included 40 patients suffering from distal and mid-penile hypospadias undergone first procedure for hypospadias, at unit of Pediatric surgery, Minia University Hospital, Egypt, from January 2014 to January 2015. Patients were divided into 2 groups of equal number. In group I TIP was performed without use of Dartos fascia flap, and in group II Dartos fascia flap was used.

The study included patients with mid- and distal primary penile hypospadias, 6 months to 12 years old. Cases with recurrent (secondary) hypospadias, age less than 6 months or above 12 years old, or cases with abnormal chromosomal studies or with severe other congenital anomalies were excluded.

All patients admitted to hospital in the morning of the operation fasting, 3-6 hours prior to surgery according to their ages. They were subjected to general anesthesia. Caudal anesthesia was given to the candidates to decrease the dose of GA, and alleviate post-operative pain.

In group I, cases had undergone TIP without dartos fascia flap. Circumscribing incision was made $2 \mathrm{~mm}$ proximal to the meatus, but if necessary, a U-shaped incision is extended proximally to healthy skin. The penis is degloved to the penoscrotal junction. The key step in the operation is a midline relaxing incision made from within the meatus to the distal extent of the plate. This incision extends through the epithelial surface of the plate deeply into underlying connective tissues down to the corpora cavernosa.

In group II, cases had undergone TIP with dartos fascia flap. After spongioplasty was done, a long Dartos flap with a completely preserved blood supply was transposed to the ventral side by a button hole maneuver (Figures 1 and 2) and sutured to the glans wings around the neomeatus, and to the corpora cavernosa up to the normally developed urethra by laterally based sutures. The neomeatus was widely fashioned and everted to prevent subsequent meatal stenosis. Thus all sutured lines were covered with at first a layer of corpus spongiosum by doing spongioplasty and second by a well-vascularized onlay Dartos flap that supports the neourethra.

All cases were discharged at the next day after surgery. Post-operative instructions are informed well to the parents. Post-operative medications were given to all patients. Dressing was removed 3 days post operatively at our outpatient clinic. Catheter was removed at the 5th day post-operative. Follow up was done routinely for all cases weekly at the outpatient clinic for two months, assessment was done and complications were reported.

The assessed postoperative items included: gapping of the suture line, fistula formation, meatal stenosis, stricture of the urethra, complete disruption of the repair, and postoperative bleeding.

The statistical analysis was carried out using the Statistical Package for the Social Sciences (SPSS 16.0 version; SPSS, Inc., Chicago, IL, USA). Categorical data were expressed as number and percent and compared using Chisquare or Fisher's exact test. Continous data were expressed as mean and standard deviation (SD) and compared using t-student test. A $P$ value of $<0.05$ was considered statistically significant.

\section{Statistical analysis:-}

The collected data were coded, tabulated, and statistically analyzed using SPSS program (Statistical Package for Social Sciences) software version 19. Descriptive statistics were done for numerical data by mean, standard deviation and minimum\& maximum of the range, while they were done for categorical data by number and percentage.

\section{Results:-}

Preoperative demographic and clinical characteristics of the studied patients are shown in table 1 . The mean age was $4 \pm 1.52$ years (range: $1-7$ years) in group I (without Dartos flap) and $5 \pm 2.13$ years (range: $1-9$ years) in group II 
(with Dartos flap). Type of hypospadias was APH in $90 \%$ in group I versus $70 \%$ in group II, and MPH in $10 \%$ of group I versus $30 \%$ in group II, with insignificant difference between both groups. The associated anomalies included 2 cases of inguinal hernia (one in each group) and 4 cases undescended testis (one in group I and 3 in group II), with insignificant difference.

The mean operative time in group I was less than that in group II $(46.25 \pm 7.58$ versus $67.5 \pm 15.76$ min. $)$ with a significant difference $(\mathrm{P}<0.001)$ (Table 2). Significant intraoperative bleeding was reported in 2 cases $(10 \%)$ of group I and 4 cases (20\%) were reported to have bleeding in group II (Table 2). Hemostasis was done using bipolar diathermy. In 3 cases of group II bleeding was reported to occur during dissection of the Dartos flap and was also controlled using bipolar diathermy. No post-operative bleeding was reported at any case of those 6 cases.

There was insignificant difference between both groups regarding postoperative complications (Table 3). Postoperative infection was reported in 2 cases (10\%) in group I and 3 cases (15\%) of group II, they were treated using topical and systemic antibiotics, unfortunately fistula developed in two of them and complete disruption occur in one of them from group I. Fistula was reported in 2 cases (10\%) in group I and 3 cases (15\%) in group 2 . In group I the 2 cases with fistula failed to be treated conservatively and needed another operation 6 months after the primary repair, while in group II two cases were treated conservatively and spontaneous closure of the fistula occurred while only one case required another operation for closure of the fistula. Complete disruption occurred only in one case in group I after extensive post-operative infection has occurred. Stricture was reported in 3 cases 2 in group 1 and 3 in group 2 all went regular dilatation and improved except one case which required meatotomy 6 months after surgery. Extensive scar was reported in one case in group I and it was the same case of complete disruption.

Table (1):- Preoperative demographic and clinical characteristics of the studied patients.

\begin{tabular}{|l|c|c|c|}
\hline Characteristics & Group I $(\mathbf{n = 2 0})$ & Group II (n=20) & P-value \\
\hline Age (years): & & & 0.10 \\
\hline Range & $1-7$ & $1-9$ & \\
\hline Mean \pm SD & $4 \pm 1.52$ & $5 \pm 2.13$ & \\
\hline Type of hypospadias: & & & \\
\hline APH & $18(90 \%)$ & $14(70 \%)$ & \\
\hline MPH & $2(10 \%)$ & $6(30 \%)$ & \\
\hline Associated anomalies: & & & 11 \\
\hline Inguinal Hernia & $1(5 \%)$ & $1(5 \%)$ & 0.29 \\
\hline Undescended testis & $1(5 \%)$ & $3(15 \%)$ & \\
\hline
\end{tabular}

Table (2):- Operative time and intra-operative bleeding in the studied patients

\begin{tabular}{|l|c|c|c|}
\hline Characteristics & Group I (n=20) & Group II (n=20) & P-value \\
\hline Operative time (min): & & & $<0.001^{*}$ \\
\hline Range & $35-65$ & $50-100$ & \\
\hline Mean \pm SD & $46.25 \pm 7.58$ & $67.5 \pm 15.76$ & 0.37 \\
\hline Intraoperative bleeding & $2(10 \%)$ & $4(20 \%)$ & \\
\hline
\end{tabular}

* Significant difference

Table (3):- Postoperative complications in the studied patients

\begin{tabular}{|c|c|c|c|}
\hline Characteristics & Group I (n=20) & Group II (n=20) & P-value \\
\hline Postoperative infection & $2(10 \%)$ & $3(15 \%)$ & 0.63 \\
\hline Fistula & $2(10 \%)$ & $3(15 \%)$ & 0.63 \\
\hline Complete disruption & $1(5 \%)$ & 0 & 0.31 \\
\hline Stricture & $2(10 \%)$ & $1(5 \%)$ & 0.54 \\
\hline Scar & $1(5 \%)$ & 0 & 0.31 \\
\hline
\end{tabular}




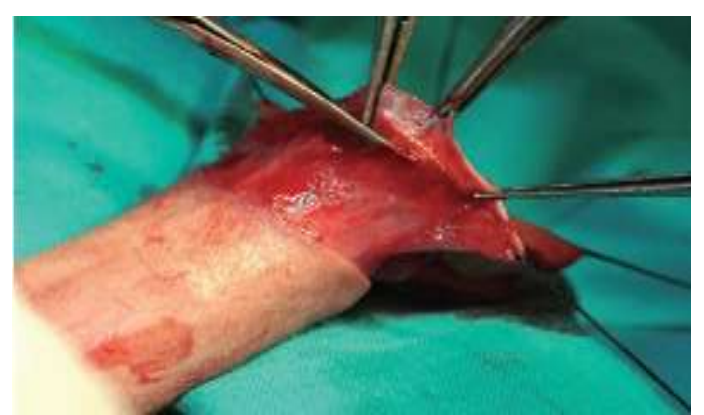

Figure (1):- Making a buttonhole incision at the Dartos flap.

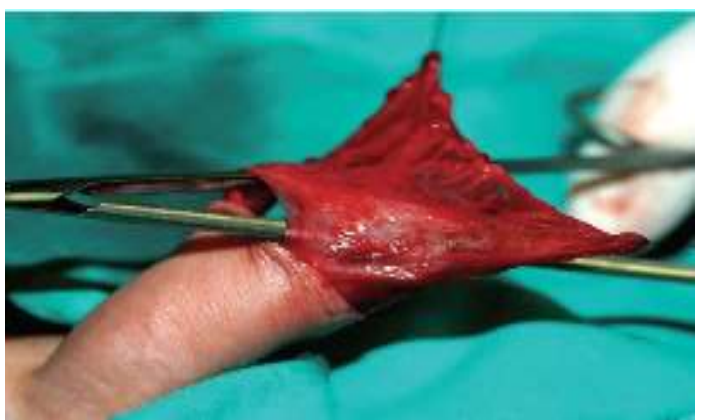

Figure (2):- Buttonhole manoeuvre for placing the dartos flap

\section{Discussion:-}

Surgery to repair hypospadias has a history of more than 150 years. There are more than 300 surgical procedures with accompanying variation have been proposed for the repair of hypospadias. Such repair should be simple, easily learned, applicable to the majority of cases, completed in a single stage with good cosmetic result with a low complication rate. Whenever possible, a single-stage repair of hypospadias is desirable [5].

Snodgrass urethroplasty is a common procedure and accepted worldwide for distal hypospadius. It is a landmark in the history of hypospadias repair. It has the lowest reported incidence of urethral fistula and meatal stenosis .however, it gives circumcised penis $[6,7]$.

Dartos fascia, harvested from the dorsal penile skin is more frequently used to cover the urethra and act as a barrier between the suture lines. Dartos based flaps have the advantage that they are available locally and do not require another incision or extension of the incision, however, this dissection requires skill and may compromise the vascularity of the skin cover resulting in subsequent dermal necrosis [8].

In the present study, the operative time was calculated from the beginning of the operation once we take the traction suture of the glans until the dressing is applied. The mean operative time was significantly different between both groups as it was $46.25 \pm 7.58$ minutes in group I (without Dartos flap), while in group II (with Dartos flap) it was $67.5 \pm 15.76$ minutes, with 21.25 minutes as a mean difference. This difference in operative time might be consumed in dissection of the Dartos flap.

In agreement with our findings, Javid et al [9] operated 30 cases of TIP using Dartos flap with mean operative time: $62 \pm 8.72$ minutes while he was comparing the results of TIP to onlay island flap in the repair of mid and posterior penile hypospadias. Also, Ghanem et al [10] reported that the mean operative time in 49 cases which did TIP using dartos flap was 180 minutes.

The incidence of infection in the present study was $10 \%$ in group I and $15 \%$ in group II. Although the difference of incidence of infection between both groups was statistically insignificant, the increased incidence of infections while using Dartos fascia flap may be explained due to increased incidence of intraoperative and post-operative bleeding and may be also caused due to necrosis of the flap due to improper dissection and affection of the vascularity of the 
flap. In a study by Hamid et al [11], the incidence of wound infection was $19.2 \%$ in 52 cases of hypospadias, while in a study by Saleem et al [12] it was $6 \%$.

In the present study, the incidence of urethrocutaneous fistula was $10 \%$ in group I, while it was $15 \%$ in group II (with Dartos flap). In a recent study by Bhat et al [4], spongioplasty alone has a lower incidence of urethrocutaneous fistula $(2.5 \%)$ than doing TIP with using Dartos flap (5\%).

Combining both the Dartos and spongiosum would increase the tissue bulk and lead to glans and skin dehiscence. The sequelae of a dorsal Dartos flap are edema, necrosis of skin, hematoma, torsion and longer operating time. Thus, spongioplasty alone is strong enough for neourethral coverage and the step of dartos cover can safely be omitted in cases where the corpus spongiosum is well developed.

In the present study stricture was reported in 2 cases $10 \%$ in group I versus 5\% in group 2 (with using Dartos flap), with insignificant difference. The adhesions between both sides of the incised plate can result in meatal stenosis that may be one if the causes of fistula formation [13]. Keeping the meatus one stitch short of complete closure reduces the rate of meatal stenosis [14].

In conclusion, the use of Dartos flap in the repair of primary cases of hypospadias in TIP repair gives no significant advantages regarding prevention of urethracutaneous fistula and meatal stenosis and it is time consuming. Spongioplasty only in TIP repair without using Dartos flap is relatively safe and rapid technique.

Conflict of interest:- All authors declare that they have no conflict of interest.

\section{References:-}

1. Rashed F, Gholizad R. Comparison of Distal Hypospadias Repair in Circumcised Patients and Uncircumcised Patients. ISRN Urology. 2013; 2013: 957581.

2. Djordjevic ML, Perovic SV, Vukadinovic VM. Dorsal dartos flap for preventing fistula in the Snodgrass hypospadias repair. BJU Int. 2005;95(9):1303-9.

3. Ahmed AA, Al-Qadi KM, Mehrez. MA. Double-Layer Dartos Flap for Neourethral Coverage in Tubularized Incised Palate Hypospadias Repair. J Am Sci. 2013;9(8):452-456.

4. Bhat A, Sabharwal K, Bhat M, Saran R, Singla M, Kumar V. Outcome of tubularized incised plate urethroplasty with spongioplasty alone as additional tissue cover: A prospective study. Indian $\mathrm{J}$ Urol. 2014;30(4):392-397.

5. Winslow BH, Devine CJ Jr. Principles in repair of hypospadias. Semin Pediatr Surg. 1996;5(1):41-8.

6. Guralnick ML, Al-Shammari A, Williot PE, Leonard MP. Outcome of Hypospadias repair using the tubularized, incised plate urethroplasty. Can J Urol. 2000;7:986- 91.

7. Baccala AA, Jr, Ross J, Detore N, Kay R. Modified tubularized incised plate urethroplasty (Snodgrass) procedure for Hypospadias repair. Urology. 2005;66:1305- 6.

8. Dhua AK, Aggarwal SK, Sinha S, Ratan SK. Soft tissue covers in hypospadias surgery: Is tunica vaginalis better than dartos flap? J Indian Assoc Pediatr Surg. 2012;17(1):16-9.

9. Javid L, Pansota MS, Ahmad I, Tariq M, Tabassum SA. Comparison between Tubularised Incised Plate Urethroplasty and Onlay Island Flap Repair in Mid and Proximal Penile Hypospadias. J Pak Med Assoc. 2014;64(4):415-8.

10. Ghanem MA, Nijman RJ. Outcome analysis of tubularized incised urethral plate using dorsal dartos flap for proximal penile hypospadias repair. J Ped Urol. 2010:457- 480.

11. Hamid R, Baba AA, Shera AH. Comparative Study of Snodgrass and Mathieu's Procedure for Primary Hypospadias Repair. ISRN Urology 2014;2014: 249765.

12. Saleem SM, Rasool M, Pansota MS, Tabasum SA. Comparative study between Tubularised Incised Plate (Snodgrass Urethroplasty and Reverse Flap (Mathieu' s) repair in distal hypospadiascie. Annals of Pakistan Institute of Medical Sciences 2012;8:96-100.

13. Elbakry A. Tubularized-incised urethral plate urethroplasty: is regular dilatation necessary for success? BJU Int. 1999;84:683- 688.

14. Guralnick ML, Al-Shammari A, Williot PE, Leonard MP. Outcome of hypospadias repair using the tubularized, incised plate urethroplasty. Can J Urol. 2000;7:986- 991. 